\section{Mouse geneticists call for unified rules of exchange}

Munich

Mouse researchers face a maze of Material Transfer Agreements (MTA) governing the exchange of research tools. A group of mouse geneticists has suggested that funding agencies should agree on a standardized, international MTA that would reduce paperwork and maximize free exchange.

The proposal comes from a task force of the International Mammalian Genome Society. It was prompted by concern about restrictions placed on the use of research tools, particularlybybiotechnology companies.

Scientists say that an increasing amount of time is spent analysing MTAs. But while many publicly funded research organizations are sympathetic to the goal of standardizing MTAs, they are sceptical as to whether the proposed contracts - one for exchange between academics and one for exchange between academics and industry — would be universally applicable.

"Everyone wants to see free exchange of research tools," says Steve Brown, director of the UK Medical Research Council's Mouse Genome Centre in Harwell and a member of the task force, which was set up in 1997. "But it will not happen overnight."

"We are not in a crisis," he says. "Ninetynine per cent of the huge number of research tools that biologists exchange are problemfree. But the issue needs to be addressed, because the one per cent of problems tend to have far-reaching consequences for basic research - for example, the Cre-loxissue."

The Cre-loxcaseled to the setting up of the task force. Cre-lox technology allows target genes to be removed from specific cells. It was patented by the pharmaceutical company DuPont, which demanded license fees and 'reach-through' rights to the profits from future discoveries made with the technology.

DuPont has agreed with the US National Institutes of Health (NIH) to allow its researchers to use Cre-lox technology without paying license fees (Nature 394, 819; 1998). But this agreement does not extend to European researchers.

As well as companies, academic institutions often demand strict MTAs. Many research bodies require first rights to negotiate a license for any invention that arises from the use of exchanged research tools.

The increasing number of MTAs "is a big administrative burden," says Philip Avner, of the Pasteur Institute's Unit of Molecular Mouse Genetics in Paris. Martin Hrabe de Angelis, head of the mouse-mutagenesis programme at the GSF, a national research centre in Munich, says that discussions with legal departments are "a waste of time". Stan- dard rules would help researchers deal with their legal departments, which tend to want strict MTAs, he says.

Unforeseen problems pop up regularly. For example, the GSF recently refused to transfer its mutant mice to NIH researchers, because the NIH insisted that the GSF accept full liability under US law for any damages resulting from the use of the mice.

The NIH has published guidelines for more relaxed and standardized MTAs (see Nature 403, 10; 2000) - again partly because of the Cre-lox controversy - which do not have such strict indemnity clauses. Its proposed standard form makes no reachthrough demands, and does not require for results to be seen before publication.

But the guidelines are only intended to cover situations with no obvious commercial implications, says one NIH official. Transfer of materials "cannot be solved on a global basis", and a standard form cannot broadly apply.

A spokesman for the MRC, which issues relatively unrestrictive MTAs between academics, agrees. "It is doubtful that a single form could serve the many different circumstances." Axel Polack of the GSF's legal department adds that the centre might be reluctant to adopt the standard form proposed by the task force: "our interests would be unlikely to be protected".

The GSF and other research centres in Germany are discussing the possibility of a single MTA strategy with the Max Planck and Fraunhofer societies, which run basic and applied research institutes, respectively.

But the participants do not see eye-toeye. A typical MTA issued by the Max Planck Society requires only that it be kept informed of research results. The GSF requires that a recipient submits any results before publication, so that it can screen these for intellectual property protection and obtain first rights to negotiate a license. Alison Abbott

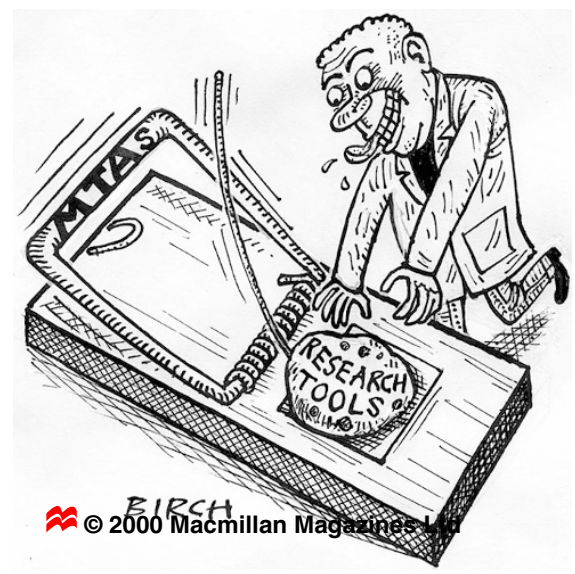

\section{Business lobby set to take EPA to court over data access}

\author{
Washington \\ Controversial rules giving greater access \\ to scientists' raw data under the US \\ Freedom of Information Act (FOIA) are \\ to be tested, following a request from the \\ US Chamber of Commerce to see data \\ held by the Environmental Protection \\ Agency (EPA).
}

The chamber has submitted three requests for the data from university studies on the sulphur content of petrol, the health effects of particulate matter and the vulnerability of poor people to pollution. The EPA used these data to justify environmental regulations.

The requests exceed the scope of the rules laid down last year by the White House Office of Management and Budget (OMB) (see Nature 401, 732; 1999). As a result, the EPA will probably refuse to release the information. But the Chamber of Commerce says that in that case it will go to court to get the data.

A court showdown would bring simmering tensions in the scientific community to the boil. Scientists have opposed FOIA access to university researchers' data, arguing that it would lead to the harassment of researchers in sensitive fields. The business community says it needs such access to challenge what it views as unreasonable regulation by the EPA and other agencies.

Harvard University's refusal to hand over data from a study on particulates led Senator Richard Shelby (Republican, Alabama) to introduce a 1998 amendment stating that "all data" from university research performed for the government should accessible under the FOIA (see Nature 397, 459; 1999).

The OMB was ordered to draw up rules to implement the amendment. But the Chamber of Commerce has dismissed these as "half-hearted".

The OMB rules exempt certain classes of data and only apply to research that underpins new regulations. The Chamber of Commerce is requesting all of the data from studies that underpin old regulations.

If refused, the Chamber will argue in court that the OMB rules conflict with the intent of both the amendment and the Freedom of Information Act itself.

University scientists are concerned that FOIA requests will be costly and may impugn their independence. The US Chamber of Commerce argues that publicly funded work should be available to the public. Colin Macilwain 